Article

\title{
Postharvest Techniques to Prevent the Incidence of Botrytis Mold of 'BRS Vitoria' Seedless Grape under Cold Storage
}

\author{
Allan Ricardo Domingues ${ }^{1}$, Sergio Ruffo Roberto ${ }^{1, *}$ (D), Saeed Ahmed ${ }^{1}$, Muhammad Shahab ${ }^{1}$, \\ Osmar José Chaves Junior ${ }^{1}$, Ciro Hideki Sumida ${ }^{1}$ and Reginaldo Teodoro de Souza ${ }^{2}$ \\ 1 Department of Agronomy, Agricultural Research Center, Londrina State University, \\ 86057-970 Londrina, PR, Brazil; allandomingez@hotmail.com (A.R.D.); saeeddikhan@gmail.com (S.A.); \\ mshahab78@gmail.com (M.S.); osmarjcj@gmail.com (O.J.C.J.); cirosumida@uel.br (C.H.S.) \\ 2 Embrapa Grape and Wine, 515, Tropical Viticulture Experimental Station, Livramento Drive, \\ 95700-000 Bento Gonçalves, RS, Brazil; reginaldo.souza@embrapa.br \\ * Correspondence: sroberto@uel.br; Tel.: +55-43-3371-4774
}

Received: 13 July 2018; Accepted: 31 July 2018; Published: 2 August 2018

\begin{abstract}
BRS Vitoria' (Vitis spp.) is a novel hybrid seedless table grape recommended for cultivation in tropical and subtropical areas, especially for overseas export. The main postharvest disease of this cultivar is botrytis or gray mold (Botrytis cinerea), which occurs even under low temperatures in cold chambers. Sulfur dioxide $\left(\mathrm{SO}_{2}\right)$ release pads have been used to control this disease under cold storage, but some grape cultivars are sensitive to certain levels of this compound. The objective of this work was to evaluate different types of $\mathrm{SO}_{2}$ generator pads in order to prevent the incidence of gray mold of 'BRS Vitoria' seedless grape, as well to avoid other grape injuries during cold storage. Grape bunches were harvested when fully ripened $\left(16^{\circ}\right.$ Brix) from a commercial field trained on overhead trellis and located at Marialva, state of Parana (PR) (South Brazil). Grapes were packed into carton boxes and subjected to the following $\mathrm{SO}_{2}$ pad treatments (Uvasys ${ }^{\circledR}$, Cape Town, South Africa) in a cold chamber $\left(2{ }^{\circ} \mathrm{C}\right.$ ): (a) control; (b) $\mathrm{SO}_{2}$ slow release pad; (c) $\mathrm{SO}_{2}$ dual release pad; (d) $\mathrm{SO}_{2}$ dual release-fast reduced pad; (e) $\mathrm{SO}_{2}$ slow release pad with grapes inoculated with $B$. cinerea; (f) $\mathrm{SO}_{2}$ dual release pad with grapes inoculated with $B$. cinerea; and (g) $\mathrm{SO}_{2}$ dual release-fast reduced pad with grapes inoculated with B. cinerea. After a 50-day cold chamber period, the grape boxes were kept for 7 days at room temperature at $25^{\circ} \mathrm{C}$. A randomized design was used with seven treatments and four replications, with five bunches per plot. The incidence of gray mold on grapes was evaluated after the 50-day cold storage and after the 7-days-at-room-temperature periods, as well other grape physicochemical variables, such as shattered berries, stem browning, bunch mass, bunch mass loss, skin color, soluble solids (SS), titratable acidity (TA), and SS/TA. The dual release pads were more efficient in preventing the incidence of gray mold and mass loss in 'BRS Vitoria' seedless grapes than the slow release pads in both storage periods. The incidence of shattered berries was lower when any type $\mathrm{SO}_{2}$ pad was used during cold storage, and no effects were observed on stem browning, firmness, or berry skin color of 'BRS Vitoria' grapes.
\end{abstract}

Keywords: Botrytis cinerea; postharvest disease; table grape; grape quality

\section{Introduction}

Released in 2012, the new hybrid seedless table grape 'BRS Vitoria' is recommended for cultivation in tropical and subtropical areas. This cultivar has good development and production, and is tolerant to downy mildew (Plasmopara viticola), one of the major grape diseases in humid areas. Due to its 
excellent flavor and firmness, this cultivar is a good option not only for the internal market, but also for export [1]. Therefore, it is necessary to develop techniques that allow postharvest conservation of this grape in cold storage for long periods.

The fungus Botrytis cinerea, which causes gray mold, is considered one of the most damaging postharvest pathogens to the quality of table grapes during storage and transport over long distances. The control of this fungus is particularly important during refrigerated storage, as it also develops at low temperatures $\left(-0.5^{\circ} \mathrm{C}\right)$ and spreads rapidly through the berry clusters [2-4].

Sulfur dioxide $\left(\mathrm{SO}_{2}\right)$ is the main fungicide treatment used to retard the growth of this fungus in refrigerated chambers, and the purpose of its use is to inhibit fungus development and to allow the storage and transport of table grapes for long periods of time [5]. There are two main concepts for packaging grapes in prolonged storage: packing with $\mathrm{SO}_{2}$ pads and fumigation of refrigeration chambers by repeated application of this gas [6,7]. Despite its effectiveness, there are restrictions for the fumigation of $\mathrm{SO}_{2}$, as this may compromise fruit flavor, cause damage to the berries, and result in excessive sulfite residues [8].

Thus, the use of $\mathrm{SO}_{2}$-generating pads was developed because they provide good and efficient control and lower risk than fumigation. Depending on the grape cultivar, different types of pads were developed, such as slow release and dual phase release, with different concentrations of $\mathrm{SO}_{2}$ [9]. The $\mathrm{SO}_{2}$-generating pads contain sodium metabisulfite, which when in contact with moisture inside the grape packaging, reacts by releasing $\mathrm{SO}_{2}$ gas [10].

The choice of $\mathrm{SO}_{2}$-generating pads should be judicious, in order to maintain the quality of the grape to its final destination, and to that end, the level of the active ingredient should be specific for each table grape cultivar. The main import markets for fresh grapes, such as the European Community and the United States, have established levels of tolerance to the use of $\mathrm{SO}_{2}$ in postharvest management, aiming at greater protection of the consumer and also of the environment, since a high gas concentration and/or residue may be harmful to man and the environment [11].

Therefore, the evaluation of techniques to avoid grape losses during postharvest storage are needed to maintain quality and profit. In this context, the objective of this work was to evaluate different types of $\mathrm{SO}_{2}$ generator pads that prevent the incidence of gray mold of 'BRS Vitoria' seedless grape, as well to avoid other grape injuries during cold storage.

\section{Materials and Methods}

Grape bunches were obtained from a commercial field of 'BRS Vitoria' seedless table grape grafted on 'IAC 766' rootstock, located at Marialva, state of Parana (PR) (South Brazil) ( $23^{\circ} 29^{\prime} \mathrm{S}, 51^{\circ} 47^{\prime} \mathrm{W}$, elevation $570 \mathrm{~m}$ ). Samples were collected from regular crops in 2018. According to the Köppen classification, the climate is type $\mathrm{Cfa}$, i.e., subtropical with an average temperature in the coldest month below $18{ }^{\circ} \mathrm{C}$, and average temperature in the warmest month above $22^{\circ} \mathrm{C}$. The maximum temperature is $31^{\circ} \mathrm{C}$, and the average annual rainfall is $1596 \mathrm{~mm}$, with a tendency for concentrated rainfall in summer. The field was selected because of its history of gray mold incidence.

Botrytis cinerea, used in this study, was isolated from infected grapes showing typical gray mold symptoms, purified and identified morphologically and molecularly [12]. The isolates were maintained on potato dextrose agar (PDA) slants and stored at $4{ }^{\circ} \mathrm{C}$ for further use. Fungal conidia were harvested from 2-week-old PDA cultures of Botrytis cinerea grown at $23 \pm 1{ }^{\circ} \mathrm{C}$. A volume of $5 \mathrm{~mL}$ of distilled water, containing $0.05 \%(v / v)$ Tween 80 , was added to a Petri plate culture. The conidia were gently dislodged from the surface with a distilled glass rod, and suspensions were filtered through three layers of cheesecloth to remove any adhering mycelia. The suspensions were diluted with sterile water and the concentration was determined with a hemacytometer. Further dilutions with sterile water were made to obtain the desired conidial concentrations. Botrytis cinerea suspension $\left(10^{6}\right.$ conidia $\left.\mathrm{mL}^{-1}\right)$ was used for grape inoculation.

Grapes were harvested at full maturity when soluble solids content reached around $16^{\circ}$ Brix, and then, bunches were subjected to the following treatments: (a) control; (b) $\mathrm{SO}_{2}$ slow release pad; 
(c) $\mathrm{SO}_{2}$ dual release pad; (d) $\mathrm{SO}_{2}$ dual release-fast reduced pad; (e) $\mathrm{SO}_{2}$ slow release pad with grapes inoculated with Botrytis cinerea; (f) $\mathrm{SO}_{2}$ dual release pad with grapes inoculated with Botrytis cinerea; (g) $\mathrm{SO}_{2}$ dual release-fast reduced pad with grapes inoculated with Botrytis cinerea. The inoculation was carried out by spraying a conidial suspension $\left(10^{6}\right.$ conidia $\left.\mathrm{mL}^{-1}\right)$. A completely randomized experimental design was used with seven treatments and four replicates, with five bunches per plot.

Before packing, bunches were subjected to forced air precooling, cleaned, and the damaged berries were removed. Then, they were standardized according to their appearance and mass $(\sim 0.5 \mathrm{~kg})$, and arranged individually in a plastic clamshell of $0.5 \mathrm{~kg}$ capacity, measuring $20 \times 10 \mathrm{~cm}$. The process of packaging the grapes followed several steps: arrangement of plastic micro perforated liner films in $4.5 \mathrm{~kg}$-capacity carton boxes measuring $50 \times 30 \times 10 \mathrm{~cm}$; deposition of a sheet of moisture-absorbing paper, measuring $37 \times 28 \mathrm{~cm}$ on the bottom of the liner; placement of plastic clamshells with grapes; arrangement of the $\mathrm{SO}_{2}$ pad on top; and sealing of liner. The cartons boxes were then placed in a cold chamber at $2{ }^{\circ} \mathrm{C}$ with high relative humidity for 50 days followed by one week of room temperature at $22 \pm 2{ }^{\circ} \mathrm{C}$. For treatments with $\mathrm{SO}_{2}$, one generator pad measuring $37 \times 28 \mathrm{~cm}$ per box provided with slow release, dual release, or dual release-fast reduced phases of sodium metabisulfite $\left(\mathrm{Na}_{2} \mathrm{~S}_{2} \mathrm{O}_{5}\right)$ (Uvasys ${ }^{\circledR}$, Cape Town, South Africa) was used, containing $3.85 \mathrm{~g} ; 4.50 \mathrm{~g}$, and $4.25 \mathrm{~g}$ of active ingredient, respectively. The dual release-fast reduced pad was designed for $\mathrm{SO}_{2}$-sensitive cultivars, since it releases $60 \%$ of the active ingredient during the first phase, and $40 \%$ during the subsequent fast reduced phase.

The incidence of gray mold on grapes was evaluated at 50 days after the beginning of cold storage and at 7 days at room temperature after the end of cold storage. The disease incidence was then obtained by the formula: disease incidence $(\%)=$ (number of infected bunches $/$ total number of bunches) $\times 100$ [12].

Stem browning development was measured by using the following scoring system: (1) fresh and green; (2) some light browning; (3) significant browning; and (4) severe browning, calculated by the weighted average of the scale value and number of bunches at each level, ranging between 1 and 4 [13] (Figure 1). The shattered berries incidence of was determined by counting the separated berries from the bunch stem inside the clamshell, and were expressed as a percentage of the total number of berries.

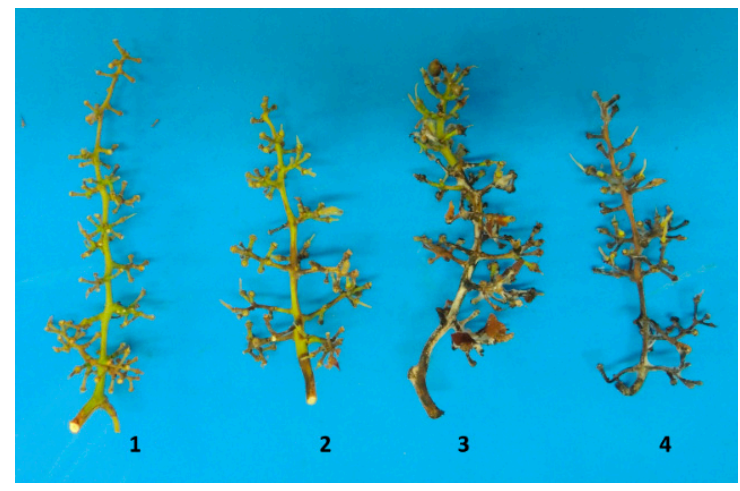

Figure 1. Stem browning scores of the 'BRS Vitoria' table grapes. 1: fresh and green; 2: light browning; 3: moderate browning; and 4: severe browning.

The bunch mass loss (\%) during postharvest storage was determined by periodic weighing, and calculated by dividing the mass change during storage by the original mass: mass loss $(\%)=[(\mathrm{mi}-\mathrm{ms}) / \mathrm{mi}] \times 100$, where $\mathrm{mi}=$ initial mass and $\mathrm{ms}=$ mass at examining time [14 $]$. The berry firmness or maximum compression force was performed with a texture analyzer TA.XTPlus (Stable Micro Systems, Surrey, UK), analyzing the equatorial position of 10 berries with pedicels per plot. Each berry was placed on the base of the equipment and compressed using a cylindrical probe with a diameter of $35 \mathrm{~mm}$ parallel to the base. A constant force of $0.05 \mathrm{~N}$ at a speed of $1.0 \mathrm{~mm} \mathrm{~s}^{-1}$ 
was applied to deform the berry to $20 \%$ of its equatorial diameter. The berry firmness $(\mathrm{N})$ was then determined [15].

Berry color was analyzed using a colorimeter Minolta ${ }^{\circledR} \mathrm{CR}-10$ to obtain the following variables from the equatorial portion of berries ( $n=2$ measurements per berry): $L^{*}$ (lightness), $C^{*}$ (chroma), and $h^{\circ}$ (hue angle) [16]. Lightness values may range from 0 (black) to 100 (white). Chroma indicates the purity or intensity of color, the distance from gray (achromatic) toward a pure chromatic color and is calculated from the $a^{*}$ and $b^{*}$ values of the CIELab scale system (International Comission on Illumination, Vienna, Austria), starting from zero for a completely neutral color, and does not have an arbitrary end, but intensity increases with magnitude. Hue refers to the color wheel and is measured in angles; green, yellow, and red correspond to $180^{\circ}, 90^{\circ}$, and $0^{\circ}$, respectively [17-19].

For chemical analysis, 15 berries were collected from each plot. The juice was used to determine soluble solids (SS) and titratable acidity (TA). SS was determined with a digital refractometer (Krüss, Hamburg, Germany) at $20^{\circ} \mathrm{C}$, and the results were expressed in ${ }^{\circ}$ Brix. The $\mathrm{pH}$ of the juice was recorded using a Jenway 3510 bench $\mathrm{pH}$ meter (Cole-Parmer, Staffordshire, UK) and then TA was determined by potentiometric titration with $\mathrm{NaOH} 0.1 \mathrm{~N}$ up to $\mathrm{pH} 8.2$, using $10 \mathrm{~mL}$ of diluted juice in $40 \mathrm{~mL}$ distilled $\mathrm{H}_{2} \mathrm{O}$, and the results were expressed in \% of tartaric acid [20]. The grape physicochemical analysis was performed at 50 days of cold storage and 7 days of room temperature.

All data were subjected to analysis of variance using Sisvar software (UFLA, Lavras, Brazil). Mean values of treatments were compared by using Scott Knott's test and judged at $p \leq 0.05$ levels.

\section{Results}

\subsection{Gray Mold Incidence (\%)}

After 50 days of cold storage, 'BRS Vitoria' table grapes submitted to treatments with $\mathrm{SO}_{2}$-generating pads presented a lower incidence of gray mold in relation to the control, and in the treatments with the dual release and fast-reduced release pads, no symptoms of the disease were observed, even when the fruit were inoculated with pathogen (Table 1).

Table 1. Gray Mold Incidence (\%) of 'BRS Vitoria' seedless table grapes at 50 days of cold storage and 7 days of room temperature under different $\mathrm{SO}_{2}$ pad treatments.

\begin{tabular}{|c|c|c|}
\hline \multirow{2}{*}{ Treatments } & \multicolumn{2}{|c|}{ Gray Mold Incidence (\%) } \\
\hline & At 50 Days in Cold Storage & At 7 Days in Room Temperature \\
\hline Control & $7.9 \pm 1.4 \mathrm{a}^{\mathrm{z}}$ & $13.0 \pm 3.0 \mathrm{a}$ \\
\hline $\mathrm{SO}_{2}$ slow release pad & $1.3 \pm 1.3 \mathrm{~b}$ & $13.4 \pm 8.4 \mathrm{a}$ \\
\hline $\mathrm{SO}_{2}$ dual release pad & $0.1 \pm 0.2 \mathrm{c}$ & $6.6 \pm 2.3 b$ \\
\hline $\mathrm{SO}_{2}$ dual release-fast reduced pad & $0.0 \pm 0.0 \mathrm{c}$ & $3.3 \pm 2.0 \mathrm{~b}$ \\
\hline $\mathrm{SO}_{2}$ slow release pad $+\mathrm{Bo}^{\mathrm{y}}$ & $1.9 \pm 0.9 \mathrm{~b}$ & $17.2 \pm 3.8 \mathrm{a}$ \\
\hline $\mathrm{SO}_{2}$ dual release pad $+\mathrm{Bo}$ & $0.3 \pm 0.5 \mathrm{c}$ & $4.7 \pm 3.2 \mathrm{~b}$ \\
\hline $\mathrm{SO}_{2}$ dual release-fast pad reduced $+\mathrm{Bo}$ & $0.0 \pm 0.0 \mathrm{c}$ & $2.5 \pm 3.3 \mathrm{~b}$ \\
\hline F value & $34.5^{* * x}$ & $5.6^{* *}$ \\
\hline \multicolumn{3}{|c|}{$\begin{array}{l}\text { z Means within columns followed by the same letters are not significantly different by Scott Knott's test }(p \leq 0.05) \text {. } \\
\text { y Bo: Botrytis inoculation. }{ }^{x * *} \text { : F value significant at } 1 \% \text {. }\end{array}$} \\
\hline \multicolumn{3}{|c|}{ In the same way, these treatments presented better performance in fungus control after 7 days at } \\
\hline \multirow{2}{*}{\multicolumn{3}{|c|}{$\begin{array}{l}\text { room temperature, where the highest incidence of gray mold was observed in treatments with slow } \\
\text { release pads, with or without inoculation }(13.4 \% \text { and } 17.2 \% \text {, respectively), and in the control }(13 \%)\end{array}$}} \\
\hline & & \\
\hline \multicolumn{3}{|c|}{ Table 1). Thus, it was verified that the slow release pad was less efficient to avoid the occurrence o } \\
\hline
\end{tabular}




\subsection{Shattered Berries and Stem Browning}

It was observed that all treatments with $\mathrm{SO}_{2}$ generator pads showed a lower percentage of shattered berries $(1.5 \%$ to $3.5 \%)$ at 50 days after refrigerated storage when compared with control $(6.1 \%)$. At 7 days after room temperature there was no difference among the treatments, and the percentage of shattered berries varied from $3.1 \%$ to $7.2 \%$ (Table 2).

Table 2. Shattered berries (\%) and stem browning scores of 'BRS Vitoria' seedless table grapes at

50 days in cold storage and 7 days of room temperature under different $\mathrm{SO}_{2}$ pad treatments.

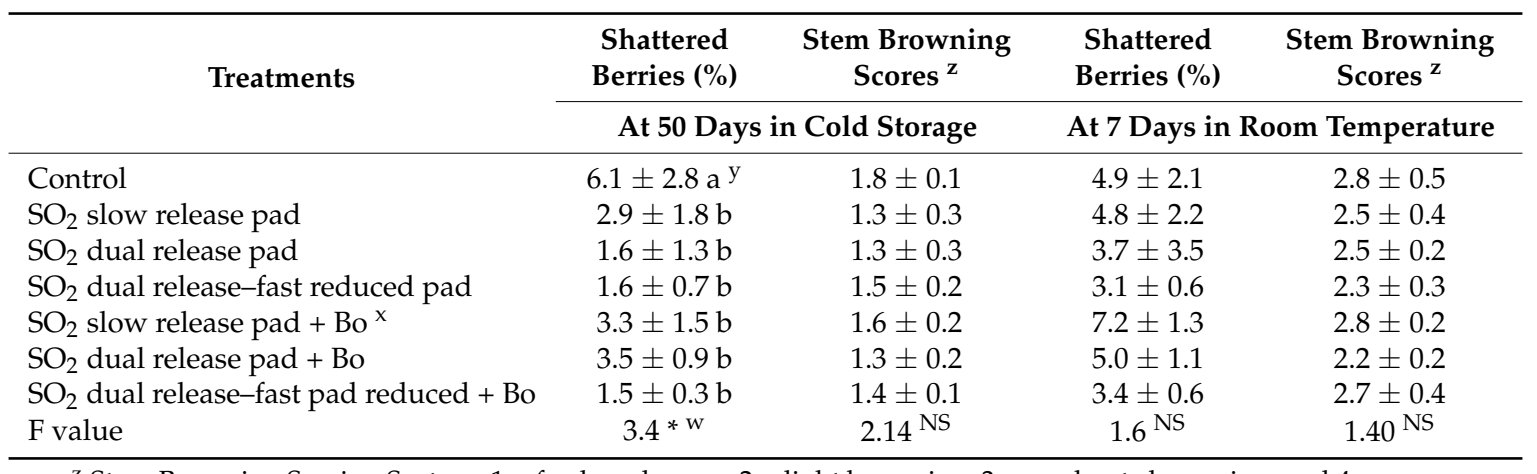

${ }^{\mathrm{z}}$ Stem Browning Scoring System: 1 = fresh and green; 2 = light browning; 3 = moderate browning; and 4 = severe browning. ${ }^{y}$ Means within columns followed by the same letters are not significantly different by Scott Knott's test $(p \leq 0.05) .{ }^{\times}$Bo: Botrytis inoculation. ${ }^{\mathrm{w}} *$ : F value significant at $5 \% .{ }^{\mathrm{NS}}$ : not significant.

The browning was not affected by the treatments in the evaluated periods. However, at 50 days after refrigerated storage, the scores were closer to 1 and 2, indicating fresh and green and browning, and after 7 days at room temperature, the scores were close to 3 , indicating moderate browning (Table 2).

\subsection{Physical Properties for Quality Measurements}

In the treatments with $\mathrm{SO}_{2}$ slow release pads, the mass loss was lower $(1.0 \%)$ than the other treatments $(1.8 \%$ to $2.4 \%)$ at 50 days after refrigerated storage. On the other hand, at 7 days at room temperature, it was observed that the treatments with $\mathrm{SO}_{2}$ dual release and dual release-fast reduced pads had lower mass loss, even when inoculated with Botrytis (0.3\% and 0.6\%) (Table 3 ).

Table 3. Mass loss and firmness of 'BRS Vitoria' seedless table grapes at 50 days of cold storage and 7 days of room temperature under different $\mathrm{SO}_{2}$ pad treatments.

\begin{tabular}{|c|c|c|c|c|}
\hline \multirow[t]{2}{*}{ Treatments } & $\begin{array}{c}\text { Mass Loss } \\
(\%)\end{array}$ & $\begin{array}{c}\text { Firmness } \\
\text { (N) }\end{array}$ & $\begin{array}{c}\text { Mass Loss } \\
(\%)\end{array}$ & $\begin{array}{c}\text { Firmness } \\
\text { (N) }\end{array}$ \\
\hline & \multicolumn{2}{|c|}{ At 50 Days in Cold Storage } & \multicolumn{2}{|c|}{ At 7 Days in Room Temperature } \\
\hline Control & $1.9 \pm 0.2 \mathrm{a}^{\mathrm{z}}$ & $11.9 \pm 1.2$ & $1.7 \pm 0.2 \mathrm{a}$ & $12.0 \pm 1.1$ \\
\hline $\mathrm{SO}_{2}$ slow release pad & $1.0 \pm 0.2 \mathrm{~b}$ & $12.7 \pm 0.4$ & $1.9 \pm 0.7 \mathrm{a}$ & $12.5 \pm 1.5$ \\
\hline $\mathrm{SO}_{2}$ dual release pad & $2.1 \pm 0.3 \mathrm{a}$ & $10.1 \pm 0.6$ & $1.1 \pm 0.1 \mathrm{~b}$ & $11.3 \pm 1.2$ \\
\hline $\mathrm{SO}_{2}$ dual release pad $+\mathrm{Bo}$ & $2.1 \pm 0.3 \mathrm{a}$ & $13.4 \pm 1.1$ & $0.6 \pm 0.3 c$ & $13.3 \pm 1.1$ \\
\hline $\mathrm{SO}_{2}$ dual release-fast pad reduced $+\mathrm{Bo}$ & $2.4 \pm 0.1 \mathrm{a}$ & $11.1 \pm 0.4$ & $0.3 \pm 0.1 \mathrm{c}$ & $12.5 \pm 1.6$ \\
\hline F value & $2.7 * x$ & $2.3^{\mathrm{NS}}$ & $12.4^{* *}$ & $2.5^{\mathrm{NS}}$ \\
\hline
\end{tabular}

\footnotetext{
${ }^{\mathrm{z}}$ Means within columns followed by the same letters are not significantly different by Scott Knott's test $(p \leq 0.05)$.
}

y Bo: Botrytis inoculation. ${ }^{x * *}, *$ : significant at $1 \%$ and $5 \%$, respectively. ${ }^{\mathrm{NS}}$ : not significant.

There was no difference between the treatments in relation to firmness of the berries 50 days after refrigerated storage and 7 days after ambient temperature; the averages varied from $10.1 \mathrm{~N}$ to $12.7 \mathrm{~N}$, and 11.3 to $14.9 \mathrm{~N}$, respectively (Table 3). 


\subsection{Chemical Properties for Quality Measurements}

Regarding the color attributes of grape berries, no differences were observed among treatments at 50 days after refrigerated storage. After 7 days at room temperature, grapes treated with $\mathrm{SO}_{2}$ dual release-fast reduced pads presented higher means of $L^{*}$, indicating a darker coloration, and when inoculated with Botrytis, lower means of $C^{*}$. In the same period, a lower $h^{\circ}$ (57.3) was observed, with saturation between orange and yellow for treatment with $\mathrm{SO}_{2}$ dual release pads with inoculation (Table 4).

There was no difference between treatments regarding the $\mathrm{pH}$ of the grapes in the evaluated periods (Table 5). The grapes treated with dual release-fast reduced and slow release pads with inoculation of Botrytis showed higher TA at 50 days after refrigerated storage. In the same period, the highest SS means were observed in treatments with slow release, dual release, and dual release-fast reduced pads with inoculation. After 7 days at room temperature, all treatments with $\mathrm{SO}_{2}$ pads inoculated with Botrytis presented higher levels of SS. The SS/AT ratio was lower in treatments with slow release pads with Botrytis inoculation, dual release, and dual release-fast reduced pads 50 days after refrigerated storage, but at 7 days at room temperature, slow release pads and all treatments inoculated with Botrytis showed higher means for this characteristic (Table 5). 
Table 4. Luminosity $\left(L^{*}\right)$, chroma $\left(C^{*}\right)$, and hue angle $\left(h^{\circ}\right)$ of 'BRS Vitoria' seedless table grape at 50 days of cold storage and 7 days of room temperature under different $\mathrm{SO}_{2}$ pad treatments.

\begin{tabular}{|c|c|c|c|c|c|c|}
\hline \multirow{2}{*}{ Treatments } & $L^{*}$ & $C^{*}$ & $h^{\circ}$ & $L^{*}$ & $C^{*}$ & $h^{\circ}$ \\
\hline & \multicolumn{3}{|c|}{ At 50 Days of Cold Storage } & \multicolumn{3}{|c|}{ At 7 Days of Room Temperature } \\
\hline Control & $20.0 \pm 0.1$ & $4.1 \pm 0.8$ & $117.6 \pm 19.3$ & $19.9 \pm 0.5 b^{z}$ & $2.8 \pm 0.1 \mathrm{a}$ & $101.1 \pm 9.5 \mathrm{a}$ \\
\hline $\mathrm{SO}_{2}$ slow release pad & $20.0 \pm 0.2$ & $3.4 \pm 0.4$ & $124.8 \pm 7.8$ & $20.0 \pm 0.6 \mathrm{~b}$ & $2.6 \pm 0.1 \mathrm{a}$ & $92.3 \pm 4.2 \mathrm{a}$ \\
\hline $\mathrm{SO}_{2}$ dual release pad & $19.5 \pm 0.3$ & $3.2 \pm 0.2$ & $118.5 \pm 7.6$ & $20.0 \pm 0.5 b$ & $2.7 \pm 0.2 \mathrm{a}$ & $92.4 \pm 11.0 \mathrm{a}$ \\
\hline $\mathrm{SO}_{2}$ dual release-fast reduced pad & $20.2 \pm 0.3$ & $3.2 \pm 0.1$ & $110.0 \pm 14.5$ & $20.1 \pm 0.3 \mathrm{~b}$ & $2.2 \pm 0.2 \mathrm{~b}$ & $95.4 \pm 15.5 \mathrm{a}$ \\
\hline $\mathrm{SO}_{2}$ slow release pad $+\mathrm{Bo}^{\mathrm{y}}$ & $19.9 \pm 0.7$ & $3.2 \pm 0.3$ & $111.3 \pm 4.5$ & $19.8 \pm 0.4 \mathrm{~b}$ & $2.6 \pm 0.4 \mathrm{a}$ & $97.0 \pm 16.1 \mathrm{a}$ \\
\hline $\mathrm{SO}_{2}$ dual release pad $+\mathrm{Bo}$ & $19.9 \pm 0.5$ & $3.2 \pm 0.4$ & $116.0 \pm 7.4$ & $20.2 \pm 0.6 \mathrm{~b}$ & $3.0 \pm 0.1 \mathrm{a}$ & $57.3 \pm 8.2 b$ \\
\hline $\mathrm{SO}_{2}$ dual release-fast pad reduced $+\mathrm{Bo}$ & $19.9 \pm 0.2$ & $3.3 \pm 0.4$ & $124.7 \pm 10.5$ & $22.2 \pm 0.4 \mathrm{a}$ & $2.1 \pm 0.4 b$ & $82.3 \pm 1.4 \mathrm{a}$ \\
\hline F value & $0.9^{\mathrm{NS} x}$ & $1.9^{\mathrm{NS}}$ & $0.8^{\mathrm{NS}}$ & $8.2 * *$ & $5.6^{* *}$ & $5.8^{* *}$ \\
\hline
\end{tabular}

${ }^{\mathrm{z}}$ Means within columns followed by the same letters are not significantly different by Scott Knott's test $(p \leq 0.05) .{ }^{\mathrm{y}}$ Bo: Botrytis inoculation. ${ }^{\mathrm{x} * *}$ : significant at $5 \%$. NS: not significant.

Table 5. $\mathrm{pH}$, soluble solids (SS), titratable acidity (TA), SS/AT of 'BRS Vitoria' seedless table grape at 50 days of cold storage, and 7 days of room temperature under different $\mathrm{SO}_{2}$ pad treatments.

\begin{tabular}{|c|c|c|c|c|c|c|c|c|}
\hline \multirow[t]{2}{*}{ Treatments } & $\mathrm{pH}$ & $\begin{array}{l}\text { Soluble } \\
\text { Solids-SS } \\
\left({ }^{\circ} \text { Brix) }\right.\end{array}$ & $\begin{array}{c}\text { Titratable } \\
\text { Acidity-TA } \\
(\%)\end{array}$ & SS/TA & $\mathrm{pH}$ & $\begin{array}{l}\text { Soluble } \\
\text { Solids-SS } \\
\quad\left({ }^{\circ} \text { Brix }\right)\end{array}$ & $\begin{array}{c}\text { Titratable } \\
\text { Acidity-TA } \\
(\%)\end{array}$ & SS/TA \\
\hline & \multicolumn{4}{|c|}{ At 50 Days of Cold Storage } & \multicolumn{4}{|c|}{ At 7 Days of Room Temperature } \\
\hline Control & $4.0 \pm 0.1$ & $17.2 \pm 0.8 \mathrm{~b}^{\mathrm{z}}$ & $0.7 \pm 0.0 \mathrm{~b}$ & $24.1 \pm 1.7 \mathrm{a}$ & $4.0 \pm 0.1$ & $16.8 \pm 0.6 \mathrm{~b}$ & $0.7 \pm 0.0$ & $25.6 \pm 1.5 \mathrm{~b}$ \\
\hline $\mathrm{SO}_{2}$ slow release pad & $4.1 \pm 0.2$ & $17.6 \pm 0.5 \mathrm{a}$ & $0.7 \pm 0.0 \mathrm{~b}$ & $24.7 \pm 1.4 \mathrm{a}$ & $4.0 \pm 0.1$ & $16.8 \pm 0.8 b$ & $0.6 \pm 0.0$ & $28.9 \pm 3.5 \mathrm{a}$ \\
\hline $\mathrm{SO}_{2}$ dual release pad & $3.9 \pm 0.1$ & $17.0 \pm 0.4 \mathrm{~b}$ & $0.8 \pm 0.0 \mathrm{~b}$ & $22.9 \pm 1.5 b$ & $4.1 \pm 0.2$ & $16.1 \pm 0.6 b$ & $0.6 \pm 0.0$ & $25.2 \pm 0.6 \mathrm{~b}$ \\
\hline $\mathrm{SO}_{2}$ dual release-fast reduced pad & $4.1 \pm 0.1$ & $17.4 \pm 0.3 \mathrm{~b}$ & $0.8 \pm 0.0 \mathrm{a}$ & $22.1 \pm 1.0 \mathrm{~b}$ & $4.1 \pm 0.2$ & $16.3 \pm 0.9 \mathrm{~b}$ & $0.6 \pm 0.0$ & $25.8 \pm 3.3 b$ \\
\hline $\mathrm{SO}_{2}$ slow release pad $+\mathrm{Bo}^{\mathrm{y}}$ & $4.0 \pm 0.1$ & $16.8 \pm 0.3 b$ & $0.8 \pm 0 \mathrm{a}$ & $20.7 \pm 1.1 b$ & $4.1 \pm 0.1$ & $17.7 \pm 0.3 \mathrm{a}$ & $0.6 \pm 0.0$ & $28.8 \pm 0.3 a$ \\
\hline $\mathrm{SO}_{2}$ dual release pad $+\mathrm{Bo}$ & $4.1 \pm 0.2$ & $18.0 \pm 0.4 \mathrm{a}$ & $0.7 \pm 0.0 \mathrm{~b}$ & $24.5 \pm 1.4 \mathrm{a}$ & $4.0 \pm 0.1$ & $17.5 \pm 0.3 \mathrm{a}$ & $0.6 \pm 0.0$ & $29.0 \pm 1.9 \mathrm{a}$ \\
\hline $\mathrm{SO}_{2}$ dual release-fast pad reduced $+\mathrm{Bo}$ & $4.1 \pm 0.2$ & $17.9 \pm 0.5 \mathrm{a}$ & $0.8 \pm 0.0 \mathrm{~b}$ & $23.5 \pm 0.4 \mathrm{a}$ & $4.2 \pm 0.1$ & $18.5 \pm 1.2 \mathrm{a}$ & $0.6 \pm 0.0$ & $29.9 \pm 2.0 \mathrm{a}$ \\
\hline F value & $0.8^{\mathrm{NS} x}$ & $2.7 *$ & $4.7^{* *}$ & $4.2 * *$ & $0.8^{\mathrm{NS}}$ & $3.4 *$ & $1.1^{\mathrm{NS}}$ & $2.4 *$ \\
\hline
\end{tabular}

${ }^{\mathrm{z}}$ Means within columns followed by the same letters are not significantly different by Scott Knott's test $(p \leq 0.05) .{ }^{\mathrm{y}}$ Bo: Botrytis inoculation. ${ }^{\mathrm{*} * *}, *$ : significant at $1 \%$ and $5 \%$, respectively. NS: not significant. 


\section{Discussion}

The fungus Botrytis cinerea, which causes gray mold, is considered one of the most harmful postharvest pathogens to table grapes, especially during transport and storage. The use of $\mathrm{SO}_{2}$-generating pads is one of the main fungus control methods, especially when grapes are stored in a cold room for prolonged periods [10], which is necessary if the objective is to export 'BRS Vitoria' seedless grape, or even to store it for the domestic market.

It was verified that the $\mathrm{SO}_{2}$ generator pads reduced the incidence of gray mold at 50 days after refrigerated storage, with emphasis on the dual release-fast reduced pads, with no symptoms of the disease, even when the pathogen was inoculated. The grapes treated with dual release pads also presented better results in the presence of the fungus at 7 days at room temperature, and were more promising than the $\mathrm{SO}_{2}$ slow release pad for 'BRS Vitoria' table grapes, which were not efficient in control of the disease. In addition, 'BRS Vitoria' seedless grape was not sensitive to $\mathrm{SO}_{2}$ emitted in the fast phase of the dual release pads tested, nor to other disorders, such as hairline, bleaching, and cracking. The use of clamshells for the refrigerated storage of this grape cultivar has been shown to be suitable for use in combination with the $\mathrm{SO}_{2}$ pads, because it allows a sufficient ventilation area for good circulation of the active ingredient in the package.

In another study, $\mathrm{SO}_{2}$ generator pads contributed to the reduction of gray mold in 'BRS Vitoria' seedless grapes after 30 days of refrigerated storage, with a minimum reduction of $80 \%$ [21], but lower than observed in this trial, since the amount of active ingredient was smaller. In addition, the use of $\mathrm{SO}_{2}$ pads in combination with packaging methods using macroperforated liners had high disease control of 'Red Globe' table grapes stored for four months [22]. The use of suitable packaging combined with the conscious and efficient use of $\mathrm{SO}_{2}$ pads and storage at low temperatures $\left(0-2{ }^{\circ} \mathrm{C}, 90-95 \% \mathrm{RH}\right)$ may contribute to the maintenance of the postharvest quality of table grapes up to 50 days [23].

The choice of $\mathrm{SO}_{2}$ pads should be judicious to maintain the quality of each table grape cultivar to its final destination, so the level of the active ingredient should be adequate, in order to not injure the fruits or to damage their flavor. The main import markets for fresh grapes, such as the European Community and the United States, have established levels of tolerance to the use of $\mathrm{SO}_{2}$ in postharvest management, aiming at greater protection of the consumers and of the environment [11].

The mechanism used by $\mathrm{SO}_{2}$ pads occurs due to the presence of moisture in the packaging of the grapes, which is absorbed by the sheets and that reacts with the active ingredient, sodium metabisulfite $\left(\mathrm{Na}_{2} \mathrm{~S}_{2} \mathrm{O}_{5}\right)$, resulting in the release of the gas to the external environment. Slow release $\mathrm{SO}_{2}$ pads have lower permeability and emit low $\mathrm{SO}_{2}$ concentrations over a long period of up to 60 days. The dual release pads contain the $\mathrm{Na}_{2} \mathrm{~S}_{2} \mathrm{O}_{5}$ enclosed between two plastic sheets, a slow release part and a fast release part, which provides different permeabilities, so the gas release takes place in a way specific to the part. The fast part releases $\mathrm{SO}_{2}$, which peaks after $24 \mathrm{~h}$, and then decreases by one week. The slow release of the dual release pads emits $\mathrm{SO}_{2}$ continuously, ensuring the presence of the gas for extended periods $[9,10]$. The use of the dual release pad in this work proved to be more efficient than the slow release pad, which leads to the belief that the $\mathrm{SO}_{2}$ fast release phase in the first $48 \mathrm{~h}$ of the dual release pads is necessary for the conservation of healthy 'BRS Vitoria' grapes, even though the pathogen had been inoculated artificially.

Bleaching and cracking on the surface of berries, and in some cases, stem browning, are unfavorable characteristics that impair the quality of the table grapes preserved in the cold, and can develop through the indiscriminate use of $\mathrm{SO}_{2}$ pads due to the release of excessive levels of the active ingredient $[22,24]$. In addition to the browning and dehydration of the rachis, the loss of water and the degradation of the berries are factors that also decrease the postharvest life of table grapes during storage and transportation $[25,26]$, and should, therefore, be considered when new techniques or materials for packaging are assessed. In this study, the $\mathrm{SO}_{2}$ pads did not affect the stem browning in the evaluated periods. The stem browning scores indicated that the rachis color was between 'fresh and green' and 'light brown' after 50 days of refrigerated storage. Other authors have observed that $\mathrm{SO}_{2}$ pads maintained a better fresh appearance by preventing browning in 'Thompson Seedless' [27] and 
'Red Globe' table grapes [28]. The green and fresh color of the rachis is more attractive to the consumer than when darker [7]; therefore, with a view to commercialization, rachis color is an important parameter to be evaluated.

Shattered and softening berries, and mass loss, are some of the consequences caused by the incidence of Botrytis cinerea in table grapes [2,3]. In this trial, the grapes packed and treated with the $\mathrm{SO}_{2}$ pads showed lower shattered berry incidence after the 50-day cold storage period, as well as a lower incidence of gray mold. In the same way, the effectiveness of gray mold control by the dual release and dual release-fast reduced pads, especially when berries were inoculated with Botrytis, minimized the mass loss of the grapes at 7 days after room temperature. Therefore, the use of $\mathrm{SO}_{2}$ pads with high efficiency in the control of Botrytis cinerea can contribute to the maintenance of these characteristics and, consequently, maintain 'BRS Vitoria' table grapes in long periods of storage, especially when the objective is to preserve grapes over 30 days.

The analysis of the quality profile of the table grapes after the refrigerated storage period, especially in conjunction with techniques such as the use of $\mathrm{SO}_{2}$ pads, is extremely important since any change in the taste or appearance of the fruit may interfere with the commercialization process. The results showed that the effects on the main quality parameters of 'BRS Vitoria' seedless table grapes when treated with $\mathrm{SO}_{2}$ pads were not considerably detrimental. According to international marketing regulations, the minimum SS contents may vary according to the grape cultivar from 14.0 to $17.5^{\circ}$ Brix and the SS/AT ratio must be equal to or higher than 20 [29]; values within what were observed in this work.

\section{Conclusions}

The dual release pads were more effective at preventing the incidence of gray mold and mass loss in 'BRS Vitoria' seedless grapes than slow release pads in both storage periods. Incidence of shattered berries were lower when any type of $\mathrm{SO}_{2}$ pad was used during cold storage, and no effects were observed on stem browning, firmness, and berry skin color of 'BRS Vitoria' grapes. In this context, conscientious and effective use of $\mathrm{SO}_{2}$ pads for packaging grapes, especially the dual release pad, enabled the long-term maintenance of 'BRS Vitoria' table grapes under refrigerated storage conditions.

Author Contributions: S.R.R. conceived the research idea; A.R.D., S.A., M.S., O.J.C.J., C.H.S. and R.T.d.S. helped during collection of the data; A.R.D. also analyzed the data and wrote the paper.

Funding: This research was funded by Brazilian Council for Scientific and Technological Development (CNPq) and The World Academy of Sciences (TWAS) grant number 190015/2014-4.

Acknowledgments: The author heartfelt thanks to the Londrina State University, Food Sciences Department and Prof. Sergio R. Roberto for his kind advisory and valuable comments used to help us with the improvement of the quality of our manuscript.

Conflicts of Interest: The authors declare no conflict of interest.

\section{References}

1. Maia, J.D.G.; Ritschel, P.; Camargo, U.A.; Souza, R.T.; Fajardo, V.T.; Naves, R.L.; Girardi, C. 'BRS Vitoria'A novel seedless table grape cultivar exhibiting special flavor and tolerance to downy mildew (Plasmopara viticola). Crop Breed. Appl. Technol. 2014, 14, 204-206. [CrossRef]

2. Bulit, J.; Dubos, B. Botrytis bunch rot and blight. In Compendium of Grape Diseases; APS Press: St. Paul, Rockville, MD, USA, 1990; pp. 13-15.

3. Celik, M.; Kalpulov, T.; Zutahy, Y.; Ish-Shalom, B.; Lurie, S.; Lichter, A. Quantitative and qualitative analysis of Botrytis inoculated on table grapes by $q$ PCR and antibodies. Postharvest Biol. Technol. 2009, 52, 235-239. [CrossRef]

4. Oliveira, C.E.V.; Magnani, M.; de Sales, C.V.; Pontes, A.L.D.S.; Campos-Takaki, G.M.; Stamford, T.C.M. Effects of postharvest treatment using chitosan from Mucor circinelloides on fungal pathogenicity and quality of table grapes during storage. Food Microbiol. 2014, 44, 211-219. [CrossRef] [PubMed] 
5. Crisosto, C.H.; Smilanick, J.L.; Dokoozlian, N.K.; Luvisi, D.A. Maintaining table grape postharvest quality for long distant markets. In Proceedings of the International Symposium on Table Grape Production, Anaheim, CA, USA, 28-29 June 1994; pp. 195-199.

6. Karabulut, O.A.; Mlikota Gabler, F.; Mansour, M.; Smilanick, J.L. Postharvest ethanol and hot water treatments of table grapes to control gray mold. Postharvest Biol. Technol. 2004, 34, 169-177. [CrossRef]

7. Lichter, A.; Gabler, F.M.; Smilanick, J.L. Control of spoilage in table grapes. Stewart Postharvest Rev. 2006. [CrossRef]

8. Lichter, A.; Zutahy, Y.; Kaplunov, T.; Shacham, Z.; Aharoni, N.; Lurie, S. The benefits of modified atmosphere of ethanol treated grapes. Acta Hortic. 2005, 682, 1739-1744. [CrossRef]

9. Fernandez-trujillo, J.P.; Obando-Ulloa, J.M.; Baró, R.; Martinez, J.A. Quality of two table grape cultivars treated with single or dual-phase release $\mathrm{SO}_{2}$ generators. J. Appl. Bot. Food Qual. 2008, 82, 1-8.

10. Lichter, A.; Zutahy, Y.; Kaplunov, T.; Lurie, S. Evaluation of table grapes storage in boxes with sulfur dioxide-releasing pads with either an internal plastic liner or external wrap. HortTechnology 2008, 18, 206-214.

11. Pires, J.C.M.; Sousa, S.I.V.; Pereira, A.M.C.; Alvim Ferraz, M.C.M.; Martins, F.G. Management of air quality monitoring using principal component and cluster analysis-Part $\mathrm{I}_{\mathrm{SO}} \mathrm{SO}_{2}$ and PM10. Atmos. Environ. 2008, 42, 1249-1260. [CrossRef]

12. Youssef, K.; Roberto, S.R. Applications of salt solutions before and after harvest affect the quality and incidence of postharvest gray mold of 'Italia' table grapes. Postharvest Biol. Technol. 2014, 87, 95-102. [CrossRef]

13. Mduduzi, E.K.N.; Mulugeta, A.D.; Umezuruik, L.O.; Chris, J.M. Performance of multi-packaging for table grapes based on airflow, cooling rates and fruit quality. J. Food Eng. 2012, 116, 613-621. [CrossRef]

14. Mattiuz, B.; Miguel, A.C.A.; Galati, V.C.; Nachtigal, J.C. Efeito da temperatura no armazenamento de uvas apirênicas minimamente processadas. Rev. Bras. Frutic. 2009, 31, 44-52. [CrossRef]

15. Lijavetzky, D.; Carbonell-Bejerano, P.; Grimplet, J.; Bravo, G.; Flores, P.; Fenoll, J.; Hellin, P.; Oliveros, J.C.; Martinez-Zapater, J.M. Berry flesh and skin ripening features in Vitis vinifera as assessed by transcriptional profiling. PLoS ONE 2012, 7, e39547. [CrossRef]

16. Koyama, R.; Assis, A.M.; Yamamoto, L.Y.; Borges, W.S.; Prudencio, S.H.; Roberto, S.R. Exogenous abscisic acid increases the anthocyanin concentration of berry and juice from 'Isabel' grapes (Vitis labrusca L.). HortScience 2014, 49, 460-464.

17. McGuire, R.G. Reporting of objective color measurements. HortScience 1992, 27, 1254-1255.

18. Lancaster, J.E.; Lister, C.; Reay, P.F.; Triggs, C.M. Influence of pigment composition on skin color in a wide range of fruits and vegetables. J. Am. Soc. Hortic. Sci. 1997, 122, 594-598.

19. Peppi, M.C.; Fidelibus, M.W.; Dokoozlian, N. Abscisic acid application timing and concentration affect firmness, pigmentation and color of 'Flame Seedless' grapes. HortScience 2006, 41, 1440-1445.

20. Youssef, K.; Roberto, S.R. Salt strategies to control Botrytis mold of 'Benitaka' table grapes and to maintain fruit quality during storage. Postharvest Biol. Technol. 2014, 95, 95-102. [CrossRef]

21. Youssef, K.; Roberto, S.; Chiarotti, F.; Koyama, R.; Hussain, I.; Souza, R. Control of Botrytis mold of the new seedless grape 'BRS Vitoria' during cold storage. Sci. Hortic. 2015, 193, 316-321. [CrossRef]

22. Zutahy, Y.; Lichter, A.; Kaplunov, T.; Lurie, S. Extended storage of 'Red Globe' grapes in modified $\mathrm{SO}_{2}$ generating pads. Postharvest Biol. Technol. 2008, 12-17. [CrossRef]

23. Zoffoli, J.P.; Latorre, B.; Naranjo, P. Hairline, a postharvest cracking disorder in table grapes induced by sulfur dioxide. Postharvest Biol. Technol. 2008, 47, 90-97. [CrossRef]

24. Lurie, S.; Pesis, E.; Gadiyeva, O.; Feygenberg, O.; Ben-Arie, R.; Kaplunov, T.; Zutahy, Y.; Lichter, A. Modified ethanol atmosphere to control decay of table grapes during storage. Postharvest Biol. Pathol. 2006, 42, 222-227. [CrossRef]

25. Zoffoli, J.P.; Latorre, B.A.; Naranjo, P. Preharvest applications of growth regulators and their effect on postharvest quality of table grapes during cold storage. Postharvest Biol. Technol. 2009, 51, 183-192. [CrossRef]

26. Meng, X.; Tian, S. Effects of preharvest application of antagonistic yeast combined with chitosan on decay and quality of harvested table grape fruit. J. Sci. Food Agric. 2009, 89, 1838-1842. [CrossRef]

27. Sölylemezoglu, G.; Agaoglu, Y.S. Research on the effect of grape guard during the cold storage of Thompson seedless cv. Acta Hortic. 1994, 368, 817-824. [CrossRef] 
28. Ozkaya, O.; Dundar, O.; Ozdemir, A.E.; Dilbaz, R. Effects of different postharvest applications on Red Globe grapes storage. Alatarm 2005, 4, 44-50. (In Turkish with English Abstract)

29. Bleinroth, E.W. Determinação do ponto de colheita. In Uva Para Exportação: Procedimentos De Colheita E Pós-Colheita; EMBRAPA—SPI/FRUPEX: Brasília, Brazil, 1993; pp. 20-21.

(c) 2018 by the authors. Licensee MDPI, Basel, Switzerland. This article is an open access article distributed under the terms and conditions of the Creative Commons Attribution (CC BY) license (http:/ / creativecommons.org/licenses/by/4.0/). 